\title{
IDENTIFIKASI POLA KARAKTER ANAK DENGAN ALGORITMA PERCEPTRON
}

\author{
Sri Ramadhany \\ STMIK Logika \\ Jl. K.L. Yos Sudarso Medan, SUMUT \\ Sriramadhany82@gmail.com
}

\begin{abstract}
Artificial Neural Network is a computational method that works like a human brain. The Perceptron algorithm is one method that exists in Artificial Neural Networks. The research carried out was the identification of children's character patterns using the Perceptron algorithm. The Perceptron algorithm is very reliable in recognizing patterns, one of which is the child's character pattern as was done in this study. The Perceptron algorithm identifies the character patterns of children through three inputs and two outputs. The three outputs are taken from nature variables, attitude variables and behavioral variables. The output is four human temperaments according to Hipocrates, namely sanguin, melancholy, choleric and plegamatic. All inputs and outputs will be converted into binary numbers to be trained with Matlab software.

Keywords - Artificial Neural Networks, Perceptron Algorithms, child character patterns, input, output, binary numbers.

Abstrak - Jaringan Syaraf Tiruan merupakan salah satu metode komputasi yang dapat bekerja seperti layaknya otak manusia. Algortima Perceptron merupakan salah satu metode yang ada pada Jaringan Syaraf Tiruan. Penelitian yang dilakukan adalah identifikasi pola karakter anak dengan menggunakan algoritma Perceptron. Algoritma Perceptron sangat handal dalam mengenali pola salah satunya yaitu pola karakter anak seperti yang dilakukan dalam penelitian ini. Algoritma Perceptron mengidentifikasi pola karakter anak melalui tiga input dan dua output. Tiga output tersebut diambil dari variabel sifat, variabel sikap dan variabel tingkah laku. Adapun output merupakan empat temperamen manusia menurut Hipocrates yaitu sanguin, melankolis, koleris dan plegamatis. Seluruh input dan output akan diubah menjadi bilangan biner untuk dilatih dengan software Matlab.
\end{abstract}

Kata Kunci - Jaringan Syaraf Tiruan, Algoritma Perceptron, pola karakter anak, input, output, bilangan biner.

\section{PENDAHULUAN}

Selama ini setiap sekolah dasar akan mengelompokkan siswa-siswi barunya berdasarkan tanggal pendaftaran. Penelitian ini dilakukan untuk mengidentifikasi pola karakter siswa- siswi SD. Peneliti menggunakan data dari SD Swasta Harapan Mandiri Medan yang duduk dikelas 1 untuk mengidentifikasi pola karakter tersebut. Identifikasi pola karakter anak dilakukan dengan menggunakan algoritma perceptron yang merupakan salah satu algoritma pelatihan yang ada pada Jaringan Syaraf Tiruan (JST).

\section{A. Rumusan Masalah}

Dari latar belakang masalah diatas maka dapat dirumuskan beberapa permasalahan :

1. Bagaimana sistem ini akan membantu guru-guru dalam mengoptimalkan hasil pembelajaran?

2. Bagaimana proses Perceptron Neural Network dalam mengidentifikasi pola karakter anak?

3. Bagaimana keakuratan Perceptron Neural Network dalam mengidentifikasi pola karakter anak?

\section{B. Batasan Masalah}

Adapun batasan masalah yang membatasi penelitian ini adalah :

1) Data yang dianalisa berupa tingkah laku dan kebiasaan siswa- siswi yang ada di kelas I SD
Harapan Mandiri Medan dari seorang guru.

2) Metode pengambilan data diperoleh dengan data sekunder berupa catatan data kebiasaan siswa-siswi yang ada di kelas I SD Harapan Mandiri Medan.

3) Metode yang digunakan yakni perceptron dan menggunakan software Matlab.

C. Tujuan Penelitian

Adapun tujuan dari penelitian ini adalah sebagai berikut :

1. Untuk mengidentifikasi pola karakter anak didik.

2. Untuk menciptakan konsep metode pembelajaran baru sehingga meningkatkan hasil pembelajaran anak.

3. Untuk merancang arsitektur jaringan yang melatih data kebiasaan anak menjadi karakter anak menggunakan perceptron.

4. Untuk membangun arsitektur jaringan yang melatih data kebiasaan anak menjadi karakter anak menggunakan perceptron.

5. Untuk menguji data kebiasaan anak dengan perceptron.

D. Perceptron

Perceptron merupakan bentuk JST yang sederhana, biasanya digunakan untuk mengklasifikasikan suatu tipe pola tertentu yanng 
sering dikenali dengan pemisahan secara linear. Walaupun merupakan bentuk jaringan yang sederhana dan memilik keterbatasan dalam pengenalan pola, Perceptron dapat menyelesaikan masalah dengan baik dibandingkan jaringan lain, apabila data tidak dapat dipisahkan secara linear, maka dapat dilakukan preprocessing terlebih dahulu untuk menghasilkan data yang dapat dipisahkan secara linear, atau menggunakan banyak perceptron dengan lapisan ganda, atau menggunakkan jaringan jenis lain yaitu backpropagation (Yessy Asry, 2011).

Perceptron memiliki prosedur belajar yang dapat menghasilkan bobot yang konvergen sehingga memungkinkan output yang didapat sesuai dengan target tiap input pola. Dengan kata lain, Perceptron salah satu metode jaringan syaraf tiruan yang mampu mengenali pola dengan baik.

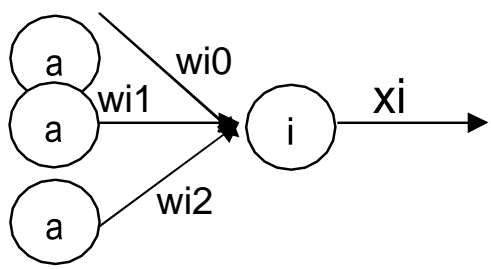

\section{Gambar 1 Unit Pengolah Perceptron}

\section{METODOLOGI PENELITIAN}

Metode yang digunakan dalam penelitian ini meliputi beberapa bagian :

1. Penelitian Lapangan (Field Research)

Yaitu penelitian yang dilakukan dengan cara meninjau langsung objek yang diteliti agar tercapainya tujuan dan hasil yang maksimal. Adapun sistematikanya adalah sebagai berikut :

a. Observasi, yaitu mengumpulkan data dengan melakukan pengamatan langsung dan pencatatan secara sistematis terhadap gejala atau fenomena yang terkait tanpa mengajukan pertanyaan yang nantinya akan menunjang dalam pembuatan sistem informasi yang baru.

b. Wawancara, yaitu mengumpulkan data dengan komunikasi langsung dengan pihak yang bersangkutan (narasumber) dengan cara mengajukan pertanyaan - pertanyaan yang mendukung permasalahan dan didapatkan suatu hasil rancangan dan data-data atau informasi yang nantinya akan menjadi penunjang dalam perancangan suatu sistem baru.

\section{Penelitian kepustakaan (Library Research)}

Merupakan cara pengumpulan data dengan mempelajari artikel - artikel, paket modul dan panduan, buku - buku pedoman dan segala kepustakaan lainnya yang dianggap perlu dan mendukung.

\section{ANALISA DAN PEMBAHASAN}

A. Identifikasi Masalah

Identifikasi masalah merupakan tahap yang digunakan untuk mencari masalah apa yang dihadapi dalam mengidentifikasi pola karakter anak. Dalam mengidentifikasi pola karakter ini penulis mengambil studi kasus di SD Harapan Mandiri Medan. Adapun data yang diambil penulis merupakan data sekunder tentang kebiasaan dan tingkah laku sehari-hari anak SD Harapan Mandiri Medan kelas I (satu).

\section{B. Analisa Masalah}

Analisa masalah merupakan tahap berikutnya yang dilakukan setelah melakukan identifikasi masalah. Setelah diperoleh masalah pada tahap sebelumnya kemudian dilakukan analisa masalah tersebut, dalam menganalisa masalah untuk mengidentifikasi pola karakter anak khususnya siswa kelas I (satu) yang ada di SD Harapan Mandiri Medan terlebih dahulu peneliti akan mencari faktor-faktor yang menyebabkan perlunya guru dalam mengidentifikasi pola karakter anak.

C. Penyelesaian masalah

Penyelesaian yang digunakan untuk mengidentifikasi pola karakter anak tersebut adalah menggunakan algoritma perceptron. Algoritma perceptron merupakan salah satu algoritma yang sangat tepat digunakan dalam mengidentifikasi pola.

Dalam mengidentifikasi pola karakter anak, algoritma perceptron memiliki tahapan- tahapan yang harus dilakukan. Adapun tahapan-tahapan yang dilakukan untuk mengidentifikasi pola karakter adalah :

1. Menentukan nilai output,

Output yang akan dihasilkan dari pelatihan ini dibatasi dengan 4 jenis temperamen dasar menurut Hipocrates. Adapun keempat jenis temperamen tersebut diberi nama sanguin, kolerik, melankolis, dan plegmatis. Masing-masing temperamen memiliki ciri khas tersendiri, berikut akan dipaparkan mengenai hal tersebut :

a. Sanguin

Golongan ini cenderung ingin populer, ingin disenangi oleh orang lain. Hidupnya penuh dengan bunga warna-warni. Mereka senang sekali bicara tanpa bisa dihentikan. Gejolak emosinya bergelombang dan transparan. Pada suatu saat ia berteriak kegirangan, dan beberapa saat kemudian dia bisa jadi menangis tersedu-sedu.

b. Koleris

Golongan koleris suka sekali mengatur orang, suka tunjuk-tunjuk atau perintah-perintah. Orang koleris tak ingin ada penonton dalam aktivitasnya. Bahkan tamu pun bisa saja disuruh melakukan sesuatu untuknya. Akibat sifatnya yang sepert "bos" ini membuat banyak orang koleris tak punya banyak teman. Orang-orang berusaha menghindar, menjauh agar tak jadi korban karakternya yang suka mengatur dan tak mau kalah itu. 
c. Melankolis

Agak berseberangan dengan sang sanguinis. Golongan melankolis cenderung serba teratur, rapi, terjadwal, tersusun sesuai pola. Umumnya mereka ini suka dengan fakta-fakta, data-data, angka-angka dan sering sekali memikirkan segalanya secara mendalam. Dalam sebuah pertemuan, orang sanguinis selalu saja mendominasi pembicaraan, namun orang melankolis cenderung menganalisa, memikirkan, mempertimbangkan, lalu kalau bicara pastilah apa yang ia katakan betul-betul hasil yang ia pikirkan secara mendalam sekali.

d. Plegmatis

Kelompok ini tak suka terjadi konflik, karena itu disuruh apa saja ia mau lakukan, sekalipun ia sendiri tak suka. Baginya kedamaian adalah segala-galanya. Jika timbul masalah atau pertengkaran, ia akan berusaha mencari solusi yang damai tanpa timbul pertengkaran. Ia mau merugi sedikit atau rela sakit, asalkan masalahnya tidak terus berkepanjangan.

Dalam menentukan output untuk pelatihan algoritma perceptron, maka keempat temparamen di atas akan diubah ke dalam bilangan biner.

Tabel 1 Pengkodean Output

\begin{tabular}{|l|l|l|}
\hline No. & \multicolumn{1}{|c|}{ Jenis } & \multicolumn{1}{c|}{ Kode } \\
\hline 1 & Sanguin & 00 \\
\hline 2 & Koleris & 01 \\
\hline 3 & Melankolis & 10 \\
\hline 4 & Plegmatis & 11 \\
\hline
\end{tabular}

2. Menentukan nilai bobot

Nilai bobot pada pelatihan ini akan diberikan secara acak. Pembelajaran dinyatakan dengan membuat aturan hubungan yang relevan antara bobot $\left(w_{i}\right)$ dengan suatu nilai threshold (nilai ambang $\square$ ). Untuk persoalan dua kelas, layer output biasanya mempunyai hanya satu node (simpul).

3. Menentukan nilai input,

Input yang akan dilatih pada algoritma ini adalah data kebiasaan anak yang telah diamati oleh wali kelas. Kebiasaan anak yang diambil adalah kebiasaan yang dominan dilakukan oleh anak tersebut. Variabel untuk menetukan karakter anak diambil dari variabel sifat, sikap dan tingkah laku anak tersebut. Seperti yang tertera pada tabel 2 :

Tabel 2 Variabel Penentu Karakter Anak

\begin{tabular}{|l|l|l|}
\hline No. & Input & \multicolumn{1}{|c|}{ Variabel } \\
\hline 1 & Input 1 & Sifat \\
\hline 2 & Input 2 & Sikap \\
\hline 3 & Input 3 & Tingkah laku \\
\hline
\end{tabular}

Berdasarkan pengelompokan variabel di atas maka setiap variabel memiliki nilai input, seperti yang tertera pada tabel 3 :

Tabel 3 Nilai Input Variabel

\begin{tabular}{|l|l|ll|}
\hline No. & Variabel & \multicolumn{2}{|c|}{ Nilai Input } \\
\hline 1 & Sifat & 1. & Pendiam \\
& & 2. & Disiplin \\
& & 3. & Periang \\
& & 4. & Pengatur \\
\hline 2 & Sikap & 1. & Sabar \\
& & 2. & Rapi \\
& & 3. & Pelupa \\
& & 4. & Sombong \\
\hline 3 & Tingkah & 1. & Pendengar Setia \\
& Laku & 2. & Konsentrasi Penuh \\
& & 3. & Sulit Konsentrasi \\
& & 4. & Lincah \\
\hline
\end{tabular}

4. Melakukan pelatihan data,

Setelah menentukan output, input dan nilai bobot maka akan dilakukan pelatihan data untuk mendapatkan output. Pelatihan akan menggunakan program MATLAB.

5. Proses Perceptron

Adapun diagram alir untuk proses perceptron yang akan digunakan dalam mengidentifikasi pola karakter anak, terdapat dua tahapan yang akan dilakukan dalam penulisan ini yaitu tahap pelatihan dan tahap pengujian.

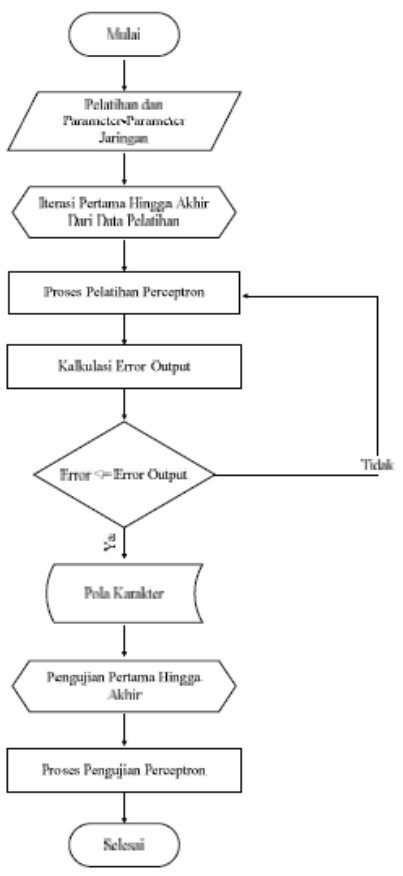

Gambar 2. Proses Perceptron 
6. Algortima dan Bahasan

Langkah berikut yang harus dilakukan adalah melakukan perhitungan manual untuk mendapatkan karater anak sebagai output. Adapun perubahan data ke dalam bilangan biner adalah sebagai berikut :

Tabel 4. Perubahan Data Sekunder sesuai Kode Biner

\begin{tabular}{|c|r|l|l|l|l|l|l|l|}
\hline NO. & NIS & $\begin{array}{c}\text { Nama } \\
\text { Lengk } \\
\text { ap } \\
\text { Siswa }\end{array}$ & K & A & \multicolumn{2}{|c|}{$\begin{array}{c}\text { Kebiasaan } \\
\text { Anak }\end{array}$} & $\begin{array}{c}\text { Karakter } \\
\text { Anak }\end{array}$ \\
\hline 1 & $\begin{array}{l}19 \\
32\end{array}$ & $\begin{array}{l}\text { Mickhael } \\
\text { Lie }\end{array}$ & L & B & 1 & 1 & 1 & 11 \\
\hline 2 & 20 & $\begin{array}{l}\text { Adit } \\
\text { ya } \\
\text { Robe } \\
\text { rto } \\
\text { Ginting }\end{array}$ & L & K & 0 & 1 & 1 & 10 \\
\hline 3 & 20 & $\begin{array}{l}\text { Agatha } \\
\text { Moniq } \\
\text { Priscilia } \\
\text { P. }\end{array}$ & P & K & 0 & 1 & 0 & 00 \\
\hline 4 & 20 & $\begin{array}{l}\text { George } \\
\text { Malea } \\
\text { khi } \\
\text { Sitorus }\end{array}$ & L & K & 1 & 0 & 1 & 01 \\
\hline
\end{tabular}

Dari data tabel 4 maka dapat kita lakukan perhitungan manual untuk menguji data, apakah algoritma perceptron akan tepat dalam mengidentifikasi pola karakter anak yaitu sebagai berikut, adapun contoh dari data yang akan digunakan adalah data Mickhael Lie dengan NIS 1932.

Perhitungan untuk mendapatkan output pertama, dengan input, bobot dan output sesuai dengan tabel 5 .

Tabel 5. Data Mickhael Lie untuk Proses Pertama

\begin{tabular}{|c|c|c|c|c|c|c|c|}
\hline $\mathbf{N}$ & \multicolumn{3}{|c|}{ Input } & \multicolumn{3}{|c|}{ Bobot } & $\begin{array}{c}\text { Outpu } \\
t\end{array}$ \\
\hline 1 & 1 & 1 & 1 & 1 & 0 & -1 & 1 \\
\hline
\end{tabular}

Perhitungan untuk mencari nilai output 1 menggunakan bobot 1 adalah menggunakan rumus nomor (10) pada bab II dan menggunakan nilai bias 1, dengan pelatihan sebagai berikut:

$$
Y 2=F A \sum_{i=0}^{3} 1
$$

$$
\begin{aligned}
& Y 1=F A \sum_{i=0}^{3}(1 x 1)+(1 x 0)+(1 x-1) \\
& +1
\end{aligned}
$$

Fungsi aktivasi dari 1 adalah 1 maka output keluaran dari perhitungan adalah 1 karena sesuai ketentuan di mana :

$F($ net $)= \begin{cases}1 & \text { Jika net } \geq 0 \\ 0 & \end{cases}$

Setelah dilakukan pelatihan untuk mencari nilai keluaran (target) maka dapat diketahui bahwa nilai target yang didapat pada proses pertama sama dengan output yang diinginkan. Dengan demikian maka dapat disimpulkan bahwa, perceptron dapat mengenali pola karakter anak dengan baik, ini disebabkan karena perceptron dapat mengenali pola karakter anak tersebut pada proses yang sangat cepat.

Setelah pelatihan untuk output 1 atas data Mickhael Lie dengan NIS 1932 berhasil dilakukan maka akan dilakukan proses hitungan manual untuk output 2 atas Mickhael Lie, adapun data yang akan dilatih :

Tabel 6 Data Mickhael Lie untuk Output 2

\begin{tabular}{|c|c|l|l|l|l|l|l|}
\hline $\begin{array}{l}\text { N } \\
\text { o. Input }\end{array}$ & \multicolumn{4}{c|}{ Bobot } & Output \\
\hline 1 & 1 & 1 & 1 & 1 & 0 & -1 & 1 \\
\hline
\end{tabular}

Berdasarkan data di atas maka akan dilakukan pelatihan untuk mencari output 2 berdasarkan data tabel 6.
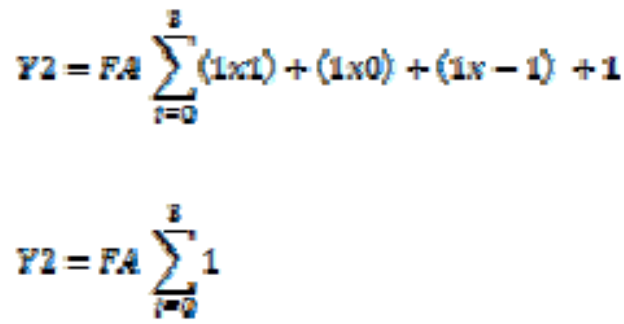

Fungsi aktivasi dari 1 adalah 1 maka output keluaran dari perhitungan adalah 1 .

Setelah dilakukan pelatihan atas data di atas, pada proses pertama juga output telah terpenuhi. Ini disebabkan karena pada output 1 dan output 2 untuk data Mickhael Lie memiliki nilai output yang sama yaitu 1,

memiliki pola input yang sama dan memiliki bobot yang sama. Karena memiliki parameter- parameter jaringan yang sama maka pelatihan yang dilakukan 
akan memiliki nilai yang sama.

Berdasarkan hitungan manual atas contoh data di atas maka dapat disimpulkan bahwa algoritma Perceptron sangat tepat dalam mengenali pola karakter anak. Ini dibuktikan dengan cepatnya proses Perceptron mengenali pola karakter anak sebagai output pada pelatihan jaringan di atas. Sebagaimana Perceptron mengenali input dari sifat, sikap dan tingkah laku anak, salah satu contohnya anak yang mempunyai sifat pendiam, sikap yang sabar dan tingkah laku sebagai pendengar setia maka pola karakter anak tersebut adalah plegmatis.

D. Implementasi

Dalam tahapan ini dijelaskan mengenai pengujian jaringan perceptron. Pengujian dilakukan menggunakan bahasa pemrograman matlab 6,1. Dalam mengimplementasikan aplikasi ini ada hal yang perlu diperhatikan yaitu software dan hardware yang mendukung pengujian ini. Di dalam pengujian ini digunakan spesifikasi software sebagai berikut:

1. Windows 7 Starter, dan

2. Matlab 6.1

Sedangkan di dalam pengujian adapun hardware yang digunakan adalah spesifikasi hardware sebagai berikut:

1. Notebook dengan prosesor intel atom

2. Harddisk $300 \mathrm{~GB}$

3. Memori RAM 1 GB

Untuk lebih jelasnya mengenai pengujian jaringan ini dapat dilihat pada keterangan berikut ini :

Input dalam software Matlab dapat melalui perintah (command line), gambar, model dan grafik. Untuk lebih jelasnya dapat dilihat pada gambar berikut :

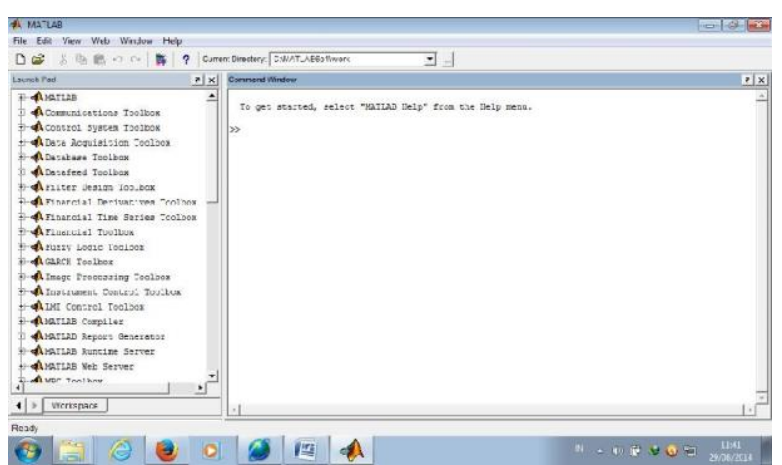

Gambar 2. Tampilan input matlab

Langkah awal yang akan dilakukan peneliti adalah membuat perintah untuk membuat jaringan Perceptron yang akan diuji perintah pada gambar di atas digunakan untuk membuat jaringan Perceptron dengan 3 input dan nilai maksimal input 1 serta nilai minimal input 0 juga mempunyai 2 output. Setelah perintah membuat jaringan maka akan dimasukkan perintah untuk pembentukan bobot jaringan pada pengujian ini akan dimasukkan bobot 1 untuk input pertama, 0 input kedua dan -1 untuk input ketiga. Setelah memasukkan nilai bobot maka akan dimasukkan nilai bias. Nilai bias yang dimasukkan adalah 1. Nilai bias diambil dari bilangan acak.

Setelah dilakukan proses pengujian iterasi maka dapat diketahui bahwa output yang dihasilkan bernilai $1 ; 1, \quad 1 ; 1, \quad 1 ; 1, \quad 1 ; 1$ dengan perolehan nilai error $0 ; 0$, $0 ;-1,-1 ;-1$, dan $-1 ; 0$. Karena masih didapati nilai error maka jaringan akan melakukan proses pengujian kembali. Jaringan Perceptron juga akan mengupdate nilai bobot dan bias untuk melakukan proses pengujian berikutnya. Update bobot dan bias akan langsung dilakukan bila pengujian jaringan dilakukan kembali. Melalui perintah ini juga maka peneliti akan mengetahui pada epoch berapakah pengujian akan berhenti dilakukan karena nilai output yang diinginkan telah terpenuhi.

Pada gambar diatas dapat peneliti ketahui bahwa output tercapai pada epoch ke 13. Adapun grafik perolehan output dapat dilihat pada gambar berikut

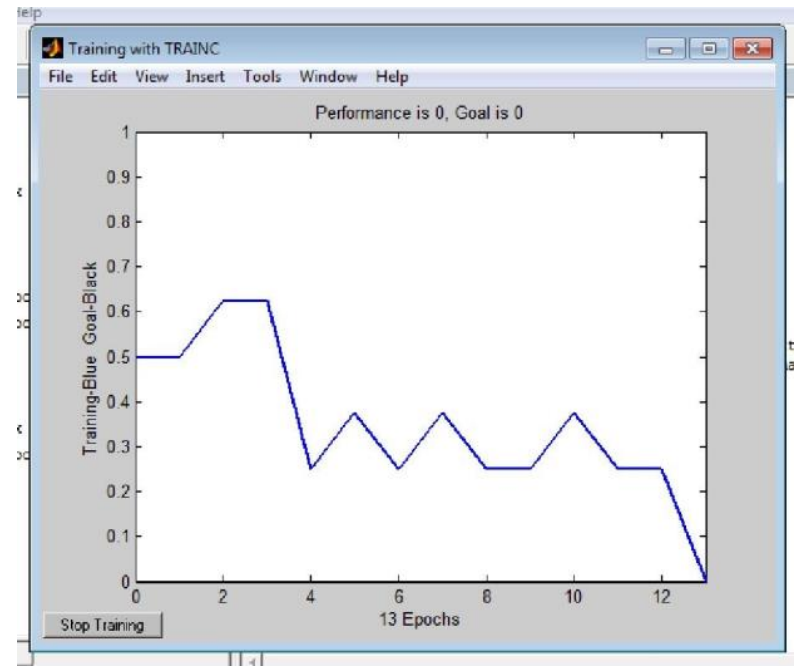

Gambar 3. Grafik perolehan input

Kesimpulan

1. Algoritma Perceptron dapat membantu guru dalam mengoptimalkan hasil pembelajaran yaitu dengan mengenali karakter setiap murid. Maka dengan itu guru akan lebih mudah dalam meningkatkan animo murid untuk belajar dan menerima pelajaran.

2. Pengujian algoritma Perceptron memberikan hasil yang sesuai dengan hasil dari komputasi manual dan hasil dari pengujian menggunakan Matlab. Hasil pengujian juga memberikan hasil yang tepat dimana pengujian menggunakan data sekunder berupa sifat, sikap dan tingkah laku anak yang merupakan variabel input dalam pengujian algoritma Perceptron. Data sekunder yang menjadi data pelatihan merupakan data hasil penilaian dari wali kelas murid. Pola karakter anak merupakan output akhir dari penelitian ini.

3. Algoritma Perceptron menguji data sekunder anak yang merupakan hasil penilaian dari wali kelas. Hasil pengujian algoritma Perceptron sangat tepat 
dan akurat dalam mengidentifikasi pola karakter anak berdasarkan data input yang telah diperoleh dari wali kelas.

\section{DAFTAR PUSTAKA}

[1] Yessy Asri (2011). "Penerapan Aturan Perceptron Pada Jaringan Saraf Tiruan Dalam Pengenalan Pola Penyakit Mata" Jurnal Pengkajian dan Penerapan Teknik Informastika. ISSN: 1978-9262. Vol 4 No 2, September 2011. Hlm. 140-146.

[2] Yaya Finayani (2011). "Mengenali Fungsi Logika AND Melalui Pemrograman Perceptron Dengan Matlab.” POLITEKNOSAINS. Vol X No. 2, Juni 2011. Hlm. 37-44.

[3] Sachin Sharma, Gaurav Kumar (2011). “Object Clasification through Perceptron Model using LabView." International Journal of Electronics and Communication Technology. ISSN: 2230-7109 (online), ISSN: 2230-9543 (Print). IJECT Vol : 2 Issue 3, September 2011, hlm. 255-258.

[4] Chandra Indrawanto (2008) "Prakiraan Harga Ekspor Mete Indonesia Dengan Menggunakan Jaringan Syaraf Tiruan" Jurnal Informatika Pertanian Vol : 17 No. 1. Hlm. 1071-1083.

[5] Ignatius Leo May (2009). "Pengenalan Vokal Bahasa Indonesia Dengan Jaringan Syaraf Tiruan Melalui Transformasi Wavelet Diskret" hlm. 1-5.

[6] Niana Laily Fitri. "Analisa dan Perancangan Untuk Penerapan Metode Artificial Neural Network (ANN) Perceptron Dalam Menentukan Penyakit Pada Daun Tembakau dan Daun Cengkeh."

[7] Adhi Sadewo Broto. (2010). "Perancangan dan Implementasi Sistem Pakar Untuk Analisa Penyakit Dalam"

[8] Sayyed Reza Khaze, Mohammad Masdari, Sohrab Hojjatkhah (2013). "Application of Artificial Neural Network in Estimating Participation in Electins.“, International Journal of Information Technology, Modeling and Computing (IJITMC) Vol : 1, No.: 3, August 2013, hlm :23-31

[9] Sahat Sonang S., Ferri Ojak Imanuel Pardede, Arifin Tua Purba (2013). "Metode Jaringan Syaraf Tiruan dalam Prediksi Serangan Jantung yang Efektif." Seminar Nasional Teknologi Informasi dan Komunikasi (SNASTIKOM), ISBN 978-60219837-2-0, hlm. 75-80

[10]Alex Rikki Sinaga (2012). “Aplikasi Jaringan Syaraf Tiruan Untuk Penentuan Konsentrasi Program Studi Bagi Calon Mahasiswa Baru STMIK Budidarma Medan." Pelita Informatika Budi Darma. Vol. 11 Desmeber 2012. ISSN 2301-924 Hlm. 1-4 